\title{
Partial two-dimensional gel electrophoresis (2-DE) maps of Streptococcus iniae ATCC29178 and Lactococcus garvieae KG9408
}

\author{
Gee-Wook Shin ${ }^{1}$, K. J. Palaksha ${ }^{1}$, Hyang-Hee Yang ${ }^{1}$, Yong-Seung Shin ${ }^{1}$, \\ Young-Rim Kim ${ }^{1}$, Eun-Young Lee ${ }^{1}$, Myung-Joo Oh ${ }^{2}$, Tae-Sung Jung ${ }^{1, *}$ \\ ${ }^{1}$ Laboratory of Fish \& Shellfish Diseases, College of Veterinary Medicine, Gyeongsang National University, Jinju 660-701, ROK \\ ${ }^{2}$ Department of Fish Pathology, Yosu National University, Yosu 550-747, ROK
}

\begin{abstract}
To examine the proteomes of 2 important causative agents of fish streptococcosis, Streptococcus iniae ATCC29178 and Lactococcus garvieae KG9408, we used 2-dimensional gel electrophoresis (2-DE) followed by mass spectrometry to generate 2-DE maps of these type strains. Silver-stained 2-DE gels of S. iniae ATCC29178 and L. garvieae KG9408 revealed 320 and 300 spots, respectively, and immobilized $\mathrm{pH}$ gradient strips $(13 \mathrm{~cm}, \mathrm{pH} 4$ to 7$)$ revealed that the majority of the detected spots were concentrated in the $\mathrm{pH}$ range of 4.5 to 5.5. The spots were randomly selected from the 2-DE profiles and identified by peptide mass fingerprinting using matrix-assisted laser desorption/ionization time of flight mass spectrometry. The majority of the identified proteins were functionally related to energy and carbohydrate metabolism (e.g. enolase ATPase, glyceraldehyde-3phosphate dehydrogenase) or translation and translocation (e.g. elongation factor G, elongation factor Tu, DNA-directed RNA polymerase alpha chain). These data, along with our partial 2-DE maps of $S$. iniae ATCC29178 and L. garvieae KG9408, may help suggest antigenic proteins for the development of effective diagnostic tools and vaccines against $S$. iniae and $L$. garvieae.
\end{abstract}

KEY WORDS: Streptococcus iniae - Lactococcus garvieae - Two-dimensional gel electrophoresis Mass spectrometry $\cdot$ Proteome

\section{INTRODUCTION}

Bacterial, viral, fungal and parasitic diseases have become major biological threats for the development and sustainability of the world fish farming industry. Fish streptococcosis, one of the most important bacterial diseases in farmed and wild fishes, occurs primarily during the warmer months in association with other contributing causes such as poor water quality (Roberts 2001, Seng \& Colorni 2002). Streptococcus iniae and Lactococcus garvieae have been identified as causative agents of streptococcosis in various species of fishes (Kusuda et al. 1976, Nakatsugawa 1983, Perera et al. 1994, Bromage et al. 1999, Eldar et al. 1999, Yuasa et al. 1999, Chang et al. 2002, Colorni et al. 2003, Kang et al. 2004). In addition, both bacteria have been isolated from human clinical samples, indicating that they may be important emerging zoonotic agents (Weinstein et al. 1997, Fefer et al. 1998). S. iniae ATCC29178 was originally isolated from skin lesions of the freshwater dolphin Inia geoffrensis (Peir \& Madin 1976), while L. garvieae KG9408 was isolated from yellowtail Seriola quinqueradiata (Ooyama et al. 2002).

Proteomics, which is widely used to study the global changes in protein expression (Blackstock \& Weir 1999), involves the separation and identification of individual proteins from cell, tissue, or organism lysates. The proteins are initially resolved by 2 -dimensional gel electrophoresis (2-DE), in which isoelectric focusing (IEF) and sodium dodecyl sulfate polyacryl- 
amide gel electrophoresis (SDS-PAGE) are used to separate proteins according to their isoelectric point (pI) and molecular weight (MW), respectively (O'Farrell 1975). In spite of available promising technologies for studying proteins, such as multidimensional protein identification, stable isotope labeling, and protein or antibody arrays, the 2-DE is the only technique that can be routinely applied for quantitative expression profiling of a complex mixture of proteins according to pI, MW, solubility, and relative abundance (Görg et al. 2004). The proteins separated by 2-DE are then identified by immunoblotting with specific antibodies (Winterhoff et al. 2002), Edman sequencing with $\mathrm{N}$-terminal sequencing (Anglade et al. 2000, Lei et al. 2000), or peptide mass fingerprinting (PMF) using matrixassisted laser desorption/ionization time of flight mass spectrometry (MALDI-TOF MS) (Cash et al. 1999, Thongboonkerd et al. 2002, Lee et al. 2003, Len et al. 2003, Lin et al. 2003, Mortz et al. 2003). The identified proteins may then be assembled into a 2-DE map or reference map of the sampled cell, tissue, or organism (Cash 2000, Cordwell et al. 2001, Champomier-Verges et al. 2002, Hughes et al. 2002, Lee et al. 2003, Len et al. 2003). Such maps have been widely used to compare differences in protein expression among strains of the same species or among the same strains under different experimental conditions. In this way, researchers have been able to study the mechanisms involved in pathogenicity, antibiotic resistance, environmental adaptation and responses to host immune systems (Cash et al. 1999, Jungblut et al. 1999, Cash 2000, Lei et al. 2000, Cordwell et al. 2001, 2002, Thongboonkerd et al. 2002, Vytvytska et al. 2002). In addition, antigenic proteins have been identified by comparing 2-DE maps and immunoblot profiles (combination of 2-DE and immunoblot assay), using computational image analysis, from various pathogenic bacteria. Computational image analysis of 2-DE maps has allowed identification of antigenic proteins in a variety of pathogenic bacteria (Cash 1999, Jungblut et al. 1999, Lei et al. 2000, Cordwell et al. 2001, Vytvytska et al. 2002).

The complete genome sequences have been established for a number of bacterial species, including the pathogenic streptococci Streptococcus pyogenes (Ferretti et al. 2001), $S$. agalactiae (Tettelin et al. 2002), $S$. pneumoniae (Tettelin et al. 2001), S. thermophilus (Bolotin et al. 2004) and S. mutans (Ajdic et al. 2002), and the lactococcus Lactococcus lactis (Bolotin et al. 2001). These sequences have given important insights into the pathogenic mechanisms of these organisms. $S$. iniae and L. garvieae belong to the genera Streptococcus and Lactococcus, respectively, and proteins of these species were identified using the available database for the related species/genera. Recently, several reports have been published on the application of the proteomics approach for identifying diagnostic markers and candidate proteins for vaccine development from various fish pathogenic bacteria, e.g. Edwardsiella tarda and Vibrio anguillarum (Kawai et al. 2004, Rao et al. 2004, Rasch et al. 2004). To our knowledge, there have been no published reports on the proteomes of S. iniae and L. garvieae, both highly important fish pathogenic bacteria found in a wide variety of fish species. In the present study we have used 2-DE, followed by PMF using MALDI-TOF MS, to construct partial proteome reference maps for $S$. iniae ATCC 29178 and L. garvieae KG9408. The results of this study may be very useful in differentiating these pathogens at the protein level and in understanding the pathogenesis of both bacteria by identifying the major proteins involved in pathogenesis.

\section{MATERIALS AND METHODS}

Preparation of bacteria. Streptococcus iniae type strain ATCC29178 was purchased from the ATCC (Manassas, USA) and L. garvieae KG9408 was kindly provided by Dr. Yoshida (Miyazaki University, Japan). Bacteria were stored in Todd-Hewitt broth (THB) containing $10 \%$ glycerol at $-70^{\circ} \mathrm{C}$. For experiments, bacteria were subcultured in triplicate in $50 \mathrm{ml} \mathrm{THB}$ at $30^{\circ} \mathrm{C}$, grown to an optical density (OD) $610 \mathrm{~nm}$ of $1.0\left(10^{9} \mathrm{CFU}\right.$ $\mathrm{ml}^{-1}$ ), and then harvested by centrifugation at $2000 \times \mathrm{g}$ for $30 \mathrm{~min}$ at $4^{\circ} \mathrm{C}$. The pellets were washed 3 times with phosphate-buffered saline (PBS; $3 \mathrm{mM} \mathrm{KCl}$, $137 \mathrm{mM} \mathrm{NaCl}, 1.5 \mathrm{mM} \mathrm{KH}_{2} \mathrm{PO}_{4}$, and $8 \mathrm{mM} \mathrm{Na}_{2} \mathrm{HPO}_{4}$, pH 7.4), and resuspended in $5 \mathrm{ml}$ of PBS. The bacterial suspensions were transferred to new tubes $(1 \mathrm{ml}$ each) and centrifuged at $2000 \times g$ for $10 \mathrm{~min}$ at $4^{\circ} \mathrm{C}$, and the resulting pellets were stored at $-20^{\circ} \mathrm{C}$ until use.

Extraction of bacterial proteins. A 2-DE sample was prepared using chemical followed by mechanical extraction methods to obtain a high abundance and good solubility of whole cell proteins (Lehner et al. 2003, Görg et al. 2004). Firstly, for chemical extraction, bacterial pellets were resuspended in $100 \mu \mathrm{l}$ of Lysis Buffer A (12 mM Tris, $5 \%$ glycerol, $0.4 \%$ SDS, and $200 \mathrm{mM}$ dithiothreitol [DTT]) and, for mechanical extraction, were sonicated 8 times (XL-2020, Misonix) at $5.5 \mathrm{~W}$ for $30 \mathrm{~s}$ in ice slurry. Cells were then disrupted by boiling for $10 \mathrm{~min}$, cooled in ice and lysed in 2-DE Lysis Buffer B consisting of $2 \mathrm{M}$ thiourea, $7 \mathrm{M}$ urea, $40 \mathrm{mM}$ Tris, $1 \%$ (w/v) DTT, $4 \%$ (w/v) 3-[(3-cholamidopropyl) dimethylammonio]-1-propanesulfonate (CHAPS) and 0.5\% (v/v) immobilized $\mathrm{pH}$ gradient (IPG)-buffer $\mathrm{pH} 4$ to 7 . The lysates were incubated on ice for $30 \mathrm{~min}$, pelleted by centrifugation at $16000 \times g$ for $30 \mathrm{~min}$ at $4^{\circ} \mathrm{C}$, and stored at $-70^{\circ} \mathrm{C}$ until use. Protein concentrations were 
estimated with the Bradford method (Bradford 1976) using bovine serum albumin (BSA) as standard. The lysed protein was diluted with double distilled water (dDW) in order to measure accurate concentration of protein and, at the same time, avoid any inhibition by chemicals including urea and SDS in Bradford assay.

2-DE. IEF and SDS-PAGE: IEF was performed using the IPGphor ${ }^{\mathrm{TM}}$ system (Amersham Bioscience) with IPG strips (Immobiline DryStrip ${ }^{\mathrm{TM}}$, pH 4 to 7, 13 cm; Amersham Bioscience), according to the previously reported method (Lee et al. 2003). The protein loading volume was adjusted to $0.6 \mathrm{mg} \mathrm{ml}^{-1}$ with rehydration buffer (9 M urea, 2\% CHAPS, $0.4 \%$ DTT, 0.5\% IPG buffer, and $0.002 \%$ bromophenol blue). The prepared sample was loaded onto the IPG strips and focusedto $86.1 \mathrm{kVh}$ using an automated programmer at $20^{\circ} \mathrm{C}$ as follows: rehydration for $14 \mathrm{~h}(7 \mathrm{~h}$ at $30 \mathrm{~V}$ followed by $7 \mathrm{~h}$ at $60 \mathrm{~V})$, and focusing for $17 \mathrm{~h}(2 \mathrm{~h}$ at $200 \mathrm{~V}, 1 \mathrm{~h}$ at $500 \mathrm{~V}, 1 \mathrm{~h} 1000$ $\mathrm{V}, 1 \mathrm{~h}$ at $2000 \mathrm{~V}, 2 \mathrm{~h}$ at $4000 \mathrm{~V}$ and $10 \mathrm{~h}$ at $8000 \mathrm{~V}$ ). After IEF, the IPG strips were equilibrated with $10 \mathrm{mg} \mathrm{ml}^{-1}$ of DTT in equilibration buffer (6 $\mathrm{M}$ urea, 2\% SDS, 30\% glycerol, $0.002 \%$ bromophenol blue, and $50 \mathrm{mM}$ Tris$\mathrm{HCl}, \mathrm{pH}$ 8.8) for $15 \mathrm{~min}$, and then with $40 \mathrm{mg} \mathrm{ml}^{-1}$ of iodoacetamide in the same buffer for another $15 \mathrm{~min}$. Equilibrated IPG strips were placed onto $12.5 \%$ SDSpolyacrylamide gels $(18 \times 16 \times 0.1 \mathrm{~cm})$, sealed with $0.5 \% \mathrm{w} / \mathrm{v}$ agarose, and electrophoresed at $10 \mathrm{~mA} \mathrm{gel}^{-1}$ for $15 \mathrm{~min}$ followed by application of $20 \mathrm{~mA} \mathrm{gel}^{-1}$ until the dye reached the bottom of the gel.

Protein visualization and image analysis: Electrophoresed gels were silver stained as previously described (Mortz et al. 2001). Briefly, each 2-DE gel was fixed with Solution A (50\% methanol, $12 \%$ acetic acid, and $0.05 \%$ [v/v] of $37 \%$ formaldehyde) for $1 \mathrm{~h}$, washed twice with $50 \%$ ethanol and sensitized with sensitizing solution $(0.01 \%$ sodium thiosulfate $)$ for $1 \mathrm{~min}$. The sensitized gels were rinsed with 3 changes of dDW and then incubated with Solution B $(0.1 \%$ silver nitrate and $0.1 \%$ of $37 \%$ formaldehyde) for $30 \mathrm{~min}$. Gels were then washed twice with dDW for $30 \mathrm{~s}$ and treated with developing solution (12\% sodium carbonate and $0.05 \%$ of $37 \%$ formaldehyde) until the desired level of staining was obtained, whereupon the developing solution was removed and the reaction was stopped by addition of Solution A without formaldehyde. The stained gels were stored in $50 \%$ methanol at $4^{\circ} \mathrm{C}$ until analysis. The gels were digitalized with an Agfa Arcus 1200 image scanner (Agfa-Gevaert), and the acquired images were analyzed using the Phoretix 2D software (Ver. 5.01, NonLinear Dynamics).

PMF for protein identification. In-gel digestion: The protein spots were in-gel digested as previously described (Lee et al. 2003). In brief, stained spots of interest were picked using a micropipette tip $(1 \mathrm{~mm}$ diameter), washed with DW followed by $50 \%$ ace- tonitrile and dried completely in a vacuum centrifuge. The dried gel pieces were rehydrated at room temperature (RT) for $45 \mathrm{~min}$ in reducing buffer $(100 \mathrm{mM}$ $\mathrm{NH}_{4} \mathrm{HCO}_{3}$ and $10 \mathrm{mM}$ DTT) and then incubated for $30 \mathrm{~min}$ in alkylation solution $\left(100 \mathrm{mM} \mathrm{NH} \mathrm{NHCO}_{3}\right.$ and $55 \mathrm{mM}$ iodoacetamide) in the dark at RT. The gel pieces were dried, rehydrated in digestion buffer (50 $\mathrm{mM} \mathrm{NH}_{4} \mathrm{HCO}_{3}$ and $12.5 \mathrm{ng} \mathrm{ml}^{-1}$ of porcine trypsin; Promega) and incubated for $45 \mathrm{~min}$ on ice. The excess liquid was removed, and $10 \mu$ l of digestion buffer without trypsin was added. Samples were incubated at $37^{\circ} \mathrm{C}$ overnight (approximately $16 \mathrm{~h}$ ). The supernatant was recovered and extracted twice with a 1:1 mixture of $5 \%$ formic acid and acetonitrile, and the extracts were pooled and dried in a vacuum centrifuge.

MALDI-TOF MS and database searches: Dried tryptic peptides were redissolved in $2 \mu$ sample solution (93:5:2 ratio of DW, acetonitrile and trifluoroacetic acid [TFA]), and the targeting on MALDI plate was performed using the solution-phase nitrocellulose method described by Lee et al. (2003). The $\alpha$-cyano-4-hydroxycinamic acid $\left(40 \mathrm{mg} \mathrm{ml}^{-1}\right)$ and nitrocellulose $(20 \mathrm{mg}$ $\mathrm{ml}^{-1}$ ) were prepared separately in acetone and mixed with isopropanol in a ratio of $2: 1: 1$. The internal standards, des-Arg-Bradykinin (monoisotopic mass, 904.4681) and Angiotensin I (1296.6853) (SigmaAldrich) were added to the mixture to generate the matrix solution, which was then mixed with the sample peptide prepared by trypsin digestion. The mixed solution $(1 \mu \mathrm{l})$ was spotted onto target circles on the MALDI plate and dried. The dried samples were sequentially washed with $5 \%$ formic acid and dDW, dried and analyzed using a Voyager-DE STR MALDI-TOF mass spectrometer (PerSeptive Bio-systems). The masses of parent ions were measured in the positive ion reflection/delayed extraction mode, with an accelerating voltage of $20 \mathrm{kV}$, a grid voltage of $76 \%$, a grid wire voltage of $0.01 \%$ and a delay time of $150 \mathrm{~ns}$. Mass spectra were obtained by irradiating the target with 128 laser pulses. Monoisotopic peptide masses were selected in the mass range of 800 to 2500 Da. Proteins were identified from the National Center for Biotechnology Information (NCBI) and SwissProt protein sequence databases using the MS-Fit program (http://prospector.ucsf.edu).

\section{RESULTS}

\section{Proteomic analysis of Streptococcus iniae ATCC29178}

In a preliminary study using IPG strips with a $\mathrm{pH}$ of 3 to 10, 2-DE profiles of Streptococcus iniae and Lactococcus garvieae showed that most spots detected by 
silver staining were concentrated in the range $\mathrm{pH} 4$ to 7 of the 2-DE gels. In addition, it was very difficult to distinguish between spots, due to overlapping. Therefore, 2-DE reference maps for both bacteria were constructed by using an IPG strip with a pH of 4 to 7 in the present study. An average of 320 spots was observed in the 2-DE profile of $S$. iniae ATCC29178 $(\mathrm{n}=3)$ after silver staining (Fig. 1). The number of spots distributed in the $\mathrm{pH}$ ranges of 4 to 5,5 to 6 and 6 to 7 were 99,140 and 81 , respectively. Approximately $50 \%$ of the spots (152 spots) were distributed in the $\mathrm{pH}$ range of 4.5 to 5.5. In terms of molecular masses, 34, 120, 98, 35 and 15 spots were detected in the ranges of 10 to 20,21 to 30,31 to 40,41 to 60 and 61 to $80 \mathrm{kDa}$, respectively.

For protein identification, the spots were randomly selected and subjected to PMF analysis. Twenty-two protein spots, corresponding to 17 different proteins, were successfully identified (Table 1). Among these, glyceraldehyde-3-phosphate dehydrogenase (GapC; Spot 11) was the only protein identified from the Streptococcus iniae database. The others were identified by comparison to protein databases of related species, yielding 2 matching proteins from $S$. mutans, 11 from $S$. pyogenes, 3 from $S$. agalactiae, and 1 from $S$. pneumonia. The 17 identified proteins were then classified into 7 functional groups (see Table 3): translation, ribosomal structure and biogenesis (4 proteins), transcription (2 proteins), posttranslational modification ( 2 proteins), nucleotide transport and metabolism (1 protein), carbohydrate transport and metabolism (5 proteins), energy production and conversion ( 2 proteins) and lipid transport and metabolism (1 protein) (www.jgi.doe.gov).

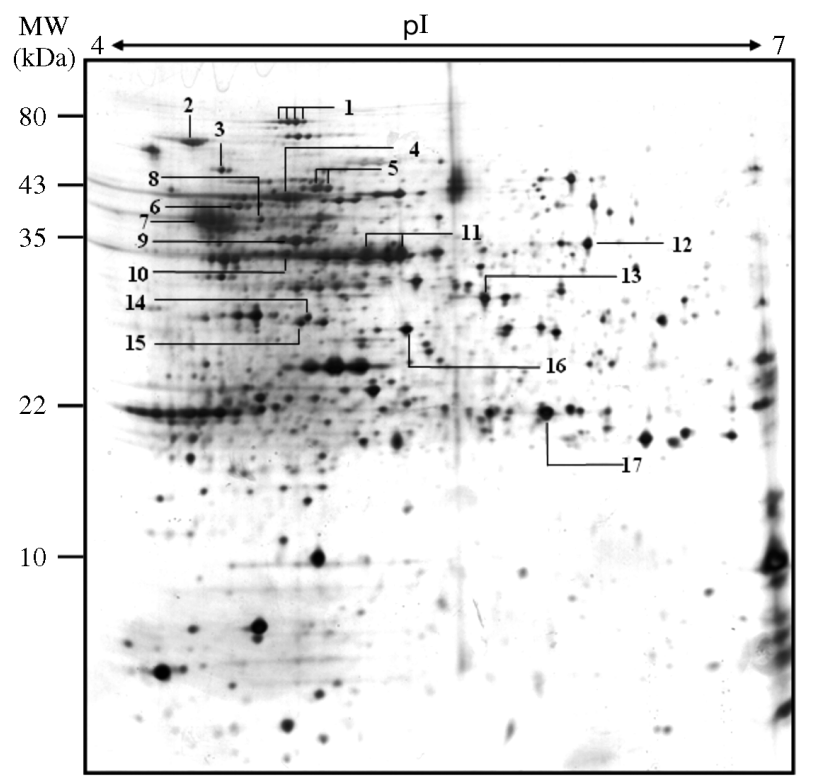

Fig. 1. Streptococcus iniae ATCC29178. A partial 2-dimensional gel electrophoresis (2-DE) map. Whole bacterial cells were lysed, and isoelectric focusing (IEF) was carried out using an immobilized $\mathrm{pH}$ gradient (IPG) dry strip ( $\mathrm{pH} 4$ to 7 , $13 \mathrm{~cm}$ ) followed by 2-DE and silver staining. Spots (1-17) were randomly selected, numbered and identified by peptide mass fingerprinting (PMF) analysis. MW: molecular weight; pI: isoelectric point

Table 1. Streptococcus iniae. Proteins identified from the $S$. iniae ATCC29178 proteome by 2-DE followed by matrix-assisted laser desorption/ionization time of flight mass spectrometry (MALDI-TOF MS) analysis and database searching. MOWSE score: molecular weight search score, scoring based on peptide frequency distribution of protein searched by the MS-Fit program (http://prospector.ucsf.edu) in protein sequence databases of the NCBI and SwissProt. pI: isoelectric point

\begin{tabular}{|c|c|c|c|c|c|c|}
\hline $\begin{array}{l}\text { Spot } \\
\text { no. }\end{array}$ & Protein & $\begin{array}{l}\text { MOWSE } \\
\text { score }\end{array}$ & $\begin{array}{l}\text { Masses } \\
\text { matched }\end{array}$ & $\begin{array}{l}\text { Cover- } \\
\text { age }(\%)\end{array}$ & $\mathrm{Da} / \mathrm{pI}$ & $\begin{array}{l}\text { Database } \\
\text { species } \\
\text { identification }\end{array}$ \\
\hline 1 & Translation elongation factor G (EF-G) & $6.01 \mathrm{E}+09$ & 19 & 36 & $76665 / 4.8$ & S. mutans \\
\hline 2 & Chaperone protein dnaK & & & & & \\
\hline & (Heat Shock Protein 70; HSP 70) & $6.65 \mathrm{E}+04$ & 8 & 19 & $64921 / 4.6$ & S. pyogenes \\
\hline 3 & GroEL protein (60 kDa chaperonin; HSP 60) & $2.29 \mathrm{E}+04$ & 6 & 16 & $57332 / 4.7$ & S. agalactiae \\
\hline 4 & Translation elongation factor TU (EF-Tu) & $1.92 \mathrm{E}+08$ & 15 & 39 & $43856 / 4.9$ & S. pyogenes \\
\hline 5 & Pyruvate kinase & $2.94 \mathrm{E}+07$ & 15 & 28 & $54536 / 5.0$ & S. pyogenes \\
\hline 6 & Ribosomal protein S1-like DNA-binding protein & $1.88 \mathrm{E}+04$ & 8 & 23 & $43850 / 4.9$ & S. pyogenes \\
\hline 7 & Enolase & $1.04 \mathrm{E}+06$ & 10 & 33 & $47357 / 4.7$ & S. pyogenes \\
\hline 8 & Proton-translocating ATPase, beta subunit & $7.51 \mathrm{E}+04$ & 8 & 23 & $51056 / 4.7$ & S. pyogenes \\
\hline 9 & Phosphoglycerate kinase & $1.18 \mathrm{E}+04$ & 7 & 27 & $42130 / 4.8$ & S. pyogenes \\
\hline 10 & $\begin{array}{l}\text { DNA-directed RNA polymerase alpha chain } \\
\text { (RNA polymerase alpha subunit) }\end{array}$ & $1.12 \mathrm{E}+05$ & 8 & 29 & $34530 / 4.9$ & S. pyogenes \\
\hline 11 & $\begin{array}{l}\text { Glyceraldehyde-3-phosphate dehydrogenase (GapC) } \\
\text { S. iniae }\end{array}$ & $1.35 \mathrm{E}+05$ & 8 & 27 & $35724 / 5.2$ & S. agalactiae \\
\hline 12 & Transcription antiterminator & $2.73 \mathrm{E}+04$ & 7 & 40 & $32529 / 6.2$ & S. pyogenes \\
\hline 13 & 6-phosphofructokinase & $1.04 \mathrm{E}+04$ & 6 & 22 & $35749 / 5.3$ & S. pyogenes \\
\hline 14 & Formate acetyltransferase (pyruvate formate-lyase) & $1.41 \mathrm{E}+04$ & 7 & 10 & $87607 / 5.2$ & S. mutans \\
\hline 15 & Acetoin dehydrogenase (TPP-dependent) beta chain & $5.34 \mathrm{E}+04$ & 11 & 30 & $35837 / 4.9$ & S. pyogenes \\
\hline 16 & $30 \mathrm{~S}$ ribosomal protein $\mathrm{S} 2$ & $1.87 \mathrm{E}+06$ & 9 & 36 & $28387 / 5.1$ & S. pneumoniae \\
\hline 17 & $\begin{array}{l}\text { Uracil phosphoribosyltransferase } \\
\text { (UMP pyrophosphorylase; UPRTase) }\end{array}$ & $1.96 \mathrm{E}+04$ & 6 & 33 & $22736 / 5.4$ & S. agalactiae \\
\hline
\end{tabular}




\section{Proteome analysis of Lactococcus garvieae KG9408}

The 2-DE profiles of Lactococcus garvieae KG9408 $(\mathrm{n}=3)$ revealed approximately 300 spots (Fig. 2), 121, 123 and 55 of which were distributed in the $\mathrm{pH}$ ranges of 4 to 5,5 to 6 and 6 to 7 , respectively. More than $50 \%$ of the spots (170 spots) were concentrated in the $\mathrm{pH}$ range of 4.5 to 5.5 . In terms of molecular mass, the spots showing relatively low intensities were distributed in the range of 15 to $32 \mathrm{kDa}$, while more intense spots were found in the range of 30 to $70 \mathrm{kDa}$. Two long horizontal streaks were found at molecular weights of 43 and $35 \mathrm{kDa}$.

For protein identification, the spots were randomly selected and subjected to PMF analysis. A total of 30 protein spots corresponding to 28 different proteins were successfully identified (Table 2). Of these, only Heat Shock Protein 60 (HSP 60, Spot 3) and 6-phosphofructokinase (Spot 20) were identified from the Lactococcus garvieae database, while the remainders were identified based on similarities to known proteins of other species in genus Lactococcus or Streptococcus. Functional analysis allowed us to divide these 28 proteins into 9 functional groups (Table 3): translation, ribosomal structure and biogenesis (6 proteins), transcription (1 protein), posttranslational modification (2 proteins), nucleotide transport and metabolism (3 proteins), carbohydrate transport and metabolism ( 7 proteins), energy production and con-

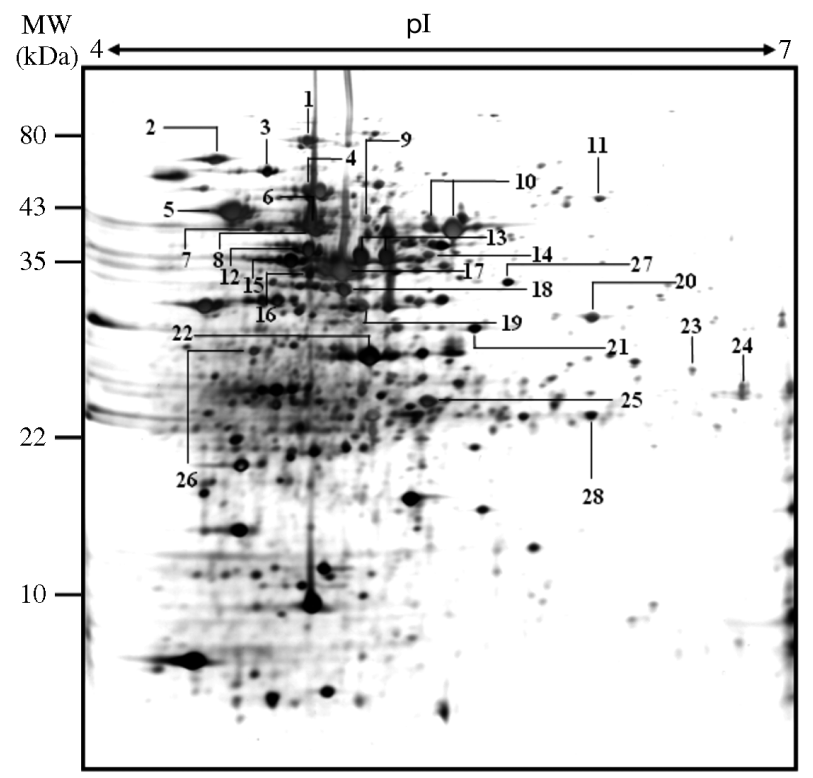

Fig. 2. Lactococcus garvieae KG9408. A partial 2-DE map. IEF was performed on whole cell lysates with an IPG dry strip ( $\mathrm{pH} 4$ to $7,13 \mathrm{~cm}$ ), followed by $12.5 \%$ sodium dodecyl sulfate polyacrylamide gel electrophoresis (SDS-PAGE) and silver staining. Spots (1-17) were randomly selected, numbered and identified by PMF analysis. MW: molecular weight; pI: isoelectric point version ( 2 proteins), amino acid transport and metabolism (2 proteins), cell wall/membrane/envelope biogenesis (4 proteins) and lipid transport and metabolism (1 protein) (www.jgi.doe.gov).

\section{DISCUSSION}

Although complete genomic sequences are available for many organisms, this information is of limited use in predicting gene and protein functions (Blackstock \& Weir 1999, Cash 2000, Cordwell et al. 2001, Champomier-Verges et al. 2002, Lin et al. 2003). Thus, proteomics has emerged as a valuable method for analyzing the genome-encoded proteins, and has proven useful for studying protein functions in cellular architecture, metabolic regulation and disease pathology (Cash 2000, Cordwell et al. 2001, Lin et al. 2003). A core method for proteomic analysis involves the use of 2-DE to separate the protein complement of a cell or tissue based on MW and pH (O'Farrell 1975), followed by identification of the separated proteins by PMF using MALDI-TOF MS and subsequent database searching (Cash et al. 1999, Thongboonkerd et al. 2002, Lee et al. 2003, Len et al. 2003, Lin et al. 2003, Mortz et al. 2003). Here, we used this technique to construct partial 2-DE reference maps for Streptococcus iniae ATCC29178 and Lactococcus garvieae KG9408.

In the 2-DE profiles of Streptococcus iniae and LaCtococcus garvieae KG9408, the majority of the protein spots were distributed at $\mathrm{pH} 4.5$ to 5.5 and MW 20 to $60 \mathrm{kDa}$. These findings are consistent with a previous report on $S$. mutans, $S$. pnumoniae and lactic acid bacteria (LAB). Len et al. (2003) detected 800, 1300, 650 and 200 spots at $\mathrm{pH} 4.0$ to $5.0,4.5$ to $5.5,5.5$ to 6.7 and 6.0 to 11.0 of IPG strips $(18 \mathrm{~cm})$, respectively, in 2 -DE profiles of $S$. mutans The majority of proteins were found below pH 6.2 in 2-DE profiles of $S$. pnumoniae (Cash et al. 1999), and at pH 4.5 to 5.5 in the LABs L. lactis, S. thermophilus, Lactobacillus delbrueckii and L. sakei (Champomier-Verges et al. 2002). Moreover, the majority of proteins predicted from the L. lactis genome were concentrated in 2 groups, the major group consisting of $56 \%$ of proteins in the pI range 3.4 to 7.0 and the minor group consisting of $33 \%$ of proteins at $\mathrm{pI}>9$ (Champomier-Verges et al. 2002). A similar pattern was also reported in theoretical proteome for S. thermophilus genomes (Arena et al. 2006). In addition, the preliminary study showed that when a pH 3 to 10 IPA strip was used both bacterial proteins were concentrated in the range of $\mathrm{pH} 4$ to 7 of the 2-DE gels using the IPG strip with a pH of 3 to 10 . The above studies show that the majority of proteins in Streptococcus spp. and LAB seem to distribute around $\mathrm{pH} 4$ to 7, particularly, at $\mathrm{pH}$ range 4.5 to 5.5 of the 2-DE gels 
Table 2. Lactococcus garvieae. Proteins identified from L. garvieae KG9408 using 2-DE followed by MALDI-TOF MS and database analysis. MOWSE: molecular weight search score, scoring based on peptide frequency distribution of protein searched by the MS-Fit program (http://prospector.ucsf.edu) in protein sequence databases of the NCBI and SwissProt. pI: isoelectric point

\begin{tabular}{|c|c|c|c|c|c|c|}
\hline $\begin{array}{l}\text { Spot } \\
\text { no. }\end{array}$ & Protein & $\begin{array}{l}\text { MOWSE } \\
\text { score }\end{array}$ & $\begin{array}{l}\text { Masses } \\
\text { matched }\end{array}$ & $\begin{array}{l}\text { Coverage } \\
(\%)\end{array}$ & $\mathrm{Da} / \mathrm{pI}$ & $\begin{array}{l}\text { Database } \\
\text { species } \\
\text { identification }\end{array}$ \\
\hline 1 & Elongation factor G (EF-G) & $1.62 \mathrm{E}+07$ & 12 & 21 & $77957 / 4.7$ & L. lactis \\
\hline 2 & $\begin{array}{l}\text { Chaperone protein dnaK } \\
\text { (Heat Shock Protein 70; HSP 70) }\end{array}$ & $2.00 \mathrm{E}+04$ & 6 & 17 & $64949 / 4.6$ & L. lactis \\
\hline 3 & $60 \mathrm{kDa}$ chaperonin (HSP 60) & $1.46 \mathrm{E}+04$ & 7 & 46 & $19924 / 4.8$ & L. garvieae \\
\hline 4 & $\begin{array}{l}\text { GMP synthase } \\
\text { (glutamine amidotransferase) }\end{array}$ & $7.77 \mathrm{E}+04$ & 8 & 17 & $56781 / 4.9$ & L. lactis \\
\hline 5 & Enolase & $2.01 \mathrm{E}+05$ & 9 & 29 & $46912 / 4.7$ & L. lactis \\
\hline 6 & Elongation factor Tu (EF-TU) & $1.58 \mathrm{E}+08$ & 14 & 33 & $43212 / 4.9$ & L. lactis \\
\hline 7 & ATP synthase alpha subunit & $8.37 \mathrm{E}+06$ & 11 & 26 & $50911 / 4.7$ & L. lactis \\
\hline 8 & 30S ribosomal protein $\mathrm{S} 1$ & $1.06 \mathrm{E}+03$ & 5 & 12 & $44710 / 5.0$ & L. lactis \\
\hline 9 & Glutamyl-tRNA synthetase & $3.15 E+04$ & 7 & 15 & $55462 / 5.1$ & L. lactis \\
\hline 10 & $\begin{array}{l}\text { Arginine deiminase } \\
\text { (arginine dehydrolase; AD) }\end{array}$ & $1.50 \mathrm{E}+06$ & 10 & 21 & $45981 / 5.1$ & L. lactis \\
\hline 11 & $\begin{array}{l}\text { Inosine-5'-monophosphate dehydrogenase } \\
\text { (IMP dehydrogenase) }\end{array}$ & $3.83 E+05$ & 12 & 29 & $52827 / 5.9$ & L. lactis \\
\hline 12 & Phosphoglycerate kinase & $1.43 \mathrm{E}+04$ & 8 & 26 & $41909 / 4.9$ & S. pneumoniae \\
\hline 13 & $\begin{array}{l}\text { Glyceraldehyde-3-phosphate } \\
\text { dehydrogenase (GapC) }\end{array}$ & $4.91 \mathrm{E}+04$ & 8 & 23 & $35907 / 5.3$ & S. uberis \\
\hline 14 & dTDP-glucose 4,6-dehydratase & $8.90 \mathrm{E}+04$ & 10 & 30 & $39461 / 5.3$ & L. lactis \\
\hline 15 & $\begin{array}{l}\text { DNA-directed RNA polymerase alpha chain } \\
\text { (RNA polymerase alpha subunit) }\end{array}$ & $8.41 \mathrm{E}+06$ & 12 & 30 & $34194 / 4.9$ & L. lactis \\
\hline 16 & Phosphomannomutase & $3.60 \mathrm{E}+03$ & 8 & 17 & $63112 / 5.1$ & S. pyogenes \\
\hline 17 & Ornithine carbamoyltransferase (OTCase) & $1.79 \mathrm{E}+04$ & 8 & 17 & $39456 / 5.4$ & L. lactis \\
\hline 18 & L-lactate dehydrogenase (L-LDH) & $1.49 \mathrm{E}+03$ & 6 & 16 & $35272 / 5.1$ & S. pyogenes \\
\hline 19 & UDP-galactose 4-epimerase & $4.58 \mathrm{E}+05$ & 9 & 35 & $36292 / 5.1$ & L. lactis \\
\hline 20 & $\begin{array}{l}\text { Similar to Lactococcus lactis } \\
\text { 6-phosphofructokinase }\end{array}$ & $2.29 \mathrm{E}+04$ & 7 & 56 & $20013 / 5.2$ & L. garvieae \\
\hline 21 & $30 \mathrm{~S}$ ribosomal protein $\mathrm{S} 2$ & $1.25 \mathrm{E}+05$ & 11 & 35 & $28539 / 5.1$ & L. lactis \\
\hline 22 & Fructose-bisphosphate aldolase & $3.70 \mathrm{E}+03$ & 7 & 40 & $31990 / 5.0$ & L. lactis \\
\hline 23 & Glu-tRNA amidotransferase subunit A & $1.12 \mathrm{E}+04$ & 8 & 19 & $52072 / 5.5$ & L. lactis \\
\hline 24 & NADH-dependent enoyl-ACP reductase & $1.59 \mathrm{E}+04$ & 7 & 25 & $26383 / 6.4$ & L. lactis \\
\hline 25 & Phosphoglycerate mutase & $1.13 \mathrm{E}+04$ & 7 & 36 & $26330 / 5.3$ & L. lactis \\
\hline 26 & Glucose-1-phosphate thymidylyltransferase & $7.72 \mathrm{E}+04$ & 7 & 34 & $32131 / 4.7$ & L. lactis \\
\hline 27 & UDP-glucose pyrophosphorylase & $1.66 \mathrm{E}+04$ & 8 & 26 & $35003 / 5.6$ & L. lactis \\
\hline 28 & $\begin{array}{l}\text { Uracil phosphoribosyltransferase } \\
\text { (UMP pyrophosphorylase) (UPRTase) }\end{array}$ & $1.27 \mathrm{E}+04$ & 6 & 20 & $23230 / 6.5$ & L. lactis \\
\hline
\end{tabular}

(Cash et al. 1999, Champomier-Verges et al. 2002, Len et al. 2003, Arena et al. 2006). Hence, the present study was conducted for constructing 2-DE reference maps of $S$. iniae and $L$. garvieae using an IPG strip with a pH of 4 to $7(13 \mathrm{~cm})$. 2-DE maps using $\mathrm{pH} 4$ to 7 in the present study, however, detected fewer spots compared with those of Len et al. (2003). This could be due to differences in protein loading volume according to the $\mathrm{pH}$ range, or the length of the IPG strip used for 2-DE.

Our PMF analysis revealed that several proteins involved in energy production and the glycolytic pathway were detected in the acidic region of the 2-DE maps, particularly at pH 4.5 to 5.5. Similarly, the majority of LAB glycolytic enzymes were reported in the same range (Champomier-Verges et al. 2002). This may indicate that the distribution of specific proteins might be similar among the species and/or that it might be a specific characteristic of the family Streptococcaceae.

Because of the limitation of Streptococcus iniae and Lactococcus garvieae databases, we used the protein databases established from the complete genome sequences of 5 species of the genus Streptococcus, S. pyogenes, S. agalactiae, S. pneumoniae, S. mutans and $S$. thermophilus, and 1 species of the genus LaCtococcus, L. lactis (Bolotin et al. 2001, 2004, Ferretti et al. 2001, Tettelin et al. 2001, 2002, Ajdic et al. 2002). We identified 17 and 28 proteins in $S$. iniae and L. garvieae from the conservative proteins of closely related species, respectively. However, it is likely that other, nonconserved proteins could be present in S. iniae ATCC29178 and L. garvieae KG9408. 
Table 3. Functional classification of proteins identified by PMF using MALDITOF MS. Classification of proteins was performed by the integrated microbial genomes (IMG) system of the Joint Genome Institute (www.jgi.doe.gov). -: unidentified protein

\begin{tabular}{|c|c|c|}
\hline \multirow[t]{2}{*}{ Functional categories } & \multicolumn{2}{|c|}{ Spot no. in 2-DE } \\
\hline & $\begin{array}{l}\text { Streptococcus } \\
\quad \text { iniae }\end{array}$ & $\begin{array}{l}\text { Lactococcus } \\
\text { garvieae }\end{array}$ \\
\hline \multicolumn{3}{|l|}{ Translation, ribosomal structure and biogenesis } \\
\hline Elongation factor $\mathrm{G}(\mathrm{EF}-\mathrm{G})$ & 1 & 1 \\
\hline Elongation factor Tu (EF-Tu) & 4 & 6 \\
\hline 30 S ribosomal protein $\mathrm{S} 1$ & - & 8 \\
\hline 30S ribosomal protein $\mathrm{S} 2$ & 16 & 21 \\
\hline Glutamyl-tRNA synthetase & - & 28 \\
\hline Ribosomal protein S1-like DNA-binding protein & 6 & - \\
\hline Glu-tRNA amidotransferase subunit A & - & 23 \\
\hline \multicolumn{3}{|l|}{ Transcription } \\
\hline Transcriptional antiterminator & 12 & - \\
\hline DNA-directed RNA polymerase alpha chain & 10 & 16 \\
\hline \multicolumn{3}{|l|}{$\begin{array}{l}\text { Posttranslational modification, protein } \\
\text { turnover, chaperones }\end{array}$} \\
\hline Heat Shock Protein 70 (HSP 70) & 2 & 2 \\
\hline HSP 60 & 3 & 3 \\
\hline \multicolumn{3}{|l|}{ Nucleotide transport and metabolism } \\
\hline Glutamine amidotransferase (GMP synthase) & - & 4 \\
\hline IMP dehydrogenase & - & 11 \\
\hline Uracil phosphoribosyltransferase (UPRTase) & 17 & 28 \\
\hline \multicolumn{3}{|l|}{ Carbohydrate transport and metabolism } \\
\hline Enolase & 7 & 5 \\
\hline Phosphoglycerate kinase (PGK) & 9 & 12 \\
\hline $\begin{array}{l}\text { Glyceraldehyde-3-phosphate dehydrogenase } \\
\text { (GAPDH) }\end{array}$ & 11 & 13 \\
\hline 6-phosphofructokinase & 13 & 20 \\
\hline Putative phosphomannomutase & - & 15 \\
\hline Phosphoglycerate mutase & - & 25 \\
\hline Pyruvate kinase & 5 & - \\
\hline Fructose-bisphosphate aldolase & - & 22 \\
\hline \multicolumn{3}{|l|}{ Energy production and conversion } \\
\hline ATP synthase alpha subunit & 8 & 7 \\
\hline Putative L-lactate dehydrogenase & - & 18 \\
\hline Formate acetyltransferase & 14 & - \\
\hline \multicolumn{3}{|l|}{ Amino acid transport and metabolism } \\
\hline Arginine deiminase (ADI) & - & 10 \\
\hline Ornithine carbamoyltransferase & - & 17 \\
\hline \multicolumn{3}{|l|}{ Cell wall/membrane/envelope biogenesis } \\
\hline dTDP-glucose 4,6-dehydratase & - & 14 \\
\hline UDP-galactose 4 -epimerase & - & 19 \\
\hline Glucose-1-phosphate thymidylyltransferase & - & 27 \\
\hline UDP-glucose pyrophosphorylase & - & 28 \\
\hline \multicolumn{3}{|l|}{ Lipid transport and metabolism } \\
\hline Acetoin dehydrogenase & 15 & - \\
\hline NADH-dependent enoyl-ACP reductase & - & 24 \\
\hline
\end{tabular}

2000, Cordwell et al. 2001, Thongboonkerd et al. 2002). Both GAPDH and enloase are known plasminogenbinding proteins that are involved in the adherence of $S$. pyogenes (Pancholi \& Fischetti 1992, Cunningham 2000), while 2-DE profiling revealed that 1 GAPDH isoform was significantly upregulated in an erythromycin-resistant strain of $S$. pneumoniae (Cash et al. 1999). In addition, HSP 70 and HSP 60 have been associated with invasion and immunodominant antigens of pathogenic bacteria (Polla et al. 1995). Similarly, 10 out of the 28 proteins identified from the 2-DE map of Lactococcus garvieae KG9408 have been previously associated with virulence, antibacterial targeting and capsule synthesis in species of Streptococcaceae. Seven of these proteins, GAPDH, enolase, HSP 70, HSP 60, arginine deiminase (AD), ornithine carbamoyltransferase (OTCase) and phosphoglycerate kinase (PGK), have been associated with virulence (Pancholi \& Fischetti 1992, Polla et al. 1995, Cash et al. 1999, Jungblut et al. 1999, Cash 2000, Cunningham 2000, Cordwell et al. 2001, Hughes et al. 2002, Thongboonkerd et al. 2002). OTCase and PGK have also been reported to act as protective antigens in $S$. agalactiae (Hughes et al. 2002). Inosine-5'monophosphate dehydrogenase (IMP dehydrogenase) and NADH-dependent enoyl-ACP reductase have been shown to act as antibacterial targets (Hedstrom 1999, Marrakchi et al. 2003), while UDP-glucose pyrophosphorylase is a capsule synthesis enzyme (Crater \& van de Rijn 1995). Thus, our partial 2-DE maps of $L$. garvieae KG9408 and $S$. iniae ATCC 29178 allowed us to successfully identify a number of proteins potentially responsible for the virulence and function of these bacteria.

Of the identified proteins, glyceraldehyde-3-phosphate dehydrogenase (GAPDH), enolase, HSP 70 and HSP 60 were identified in the 2-DE map of Streptococcus iniae ATCC29178. These proteins have previously been associated with virulence and antibiotic resistance (Pancholi \& Fischetti 1992, Polla et al. 1995, Cash et al. 1999, Cash 2000, Cunningham
Proteomic approaches have been widely used to study the pathogenic Streptococcus species for their pathogenicity mechanisms, antibiotic resistances and abilities to adapt to adverse conditions and host immune responses (Cash et al. 1999, Cash 2000, Lei et al. 2000, Cordwell et al. 2001, Hughes et al. 2002, Thongboonkerd et al. 2002, Len et al. 2003). However, while $S$. 
iniae and Lactococcus garvieae are serious biological threats to the development and sustainability of fish farming, little is known about the pathogenesis of these bacteria. Here, we report preliminary partial 2-DE reference maps of S. iniae ATCC29178 and L. garvieae KG9408. These proteomes may provide useful information for the development of effective diagnostic tools and vaccines against $S$. iniae and $L$. garvieae.

Acknowledgements. The Lactococcus garvieae KG9408 strain used in this study was kindly provided by Dr. Yoshida (Department of Fisheries, Faculty of Agriculture, Miyazaki University, Miyazaki, Japan). This work was supported by a grant (R01-2001-000-00242-0) from the Basic Research Program of the Korea Science \& Engineering Foundation.

\section{LITERATURE CITED}

Ajdic D, McShan WM, McLaughlin RE, Savic G and 15 others (2002) Genome sequence of Streptococcus mutans UA159, a cariogenic dental pathogen. Proc Natl Acad Sci USA 99(22):14434-11439

Anglade P, Demey E, Labas V, Le Caer JP, Chich JF (2000) Towards a proteomic map of Lactococcus lactis NCDO 763. Electrophoresis 21(12):2546-2549

Arena S, D'Ambrosio C, Renzone G, Rullo R and 6 others (2006) A study of Streptococcus thermophilus proteome by integrated analytical procedures and differential expression investigations. Proteomics 6(1):181-192

Blackstock WP, Weir MP (1999) Proteomics: quantitative and physical mapping of cellular proteins. Trends Biotechnol 17(3):121-127

Bolotin A, Wincker P, Mauger S, Jaillon O, Malarme K, Weissenbach J, Ehrlich SD, Sorokin A (2001) The complete genome sequence of the lactic acid bacterium Lactococcus lactis ssp. lactis IL1403. Genome Res 11(5):731-753

Bolotin A, Quinquis B, Renault P, Sorokin A and 19 others (2004) Complete sequence and comparative genome analysis of the dairy bacterium Streptococcus thermophilus. Nat Biotechnol 22(12):1554-1558

Bradford MM (1976) A rapid and sensitive method for the quantitation of microgram quantities of protein utilizing the principle of protein-dye binding. Anal Biochem 72: 248-254

Bromage ES, Thomas A, Owens L (1999) Streptococcus iniae, a bacterial infection in barramundi Lates calcarifer. Dis Aquat Org 31:177-181

Cash P (2000) Proteomics in medical microbiology. Electrophoresis 21(6):1187-1201

Cash P, Argo E, Ford L, Lawrie L, McKenzie H (1999) A proteomic analysis of erythromycin resistance in Streptococcus pneumoniae. Electrophoresis 20(11):2259-2268

Champomier-Verges MC, Maguin E, Mistou MY, Anglade P, Chich JF (2002) Lactic acid bacteria and proteomics: current knowledge and perspectives. J Chromatogr B 771(1-2):329-342

Chang PH, Lin CW, Lee YC (2002) Lactococcus garvieae infection of cultured rainbow trout, Oncorhynchus mykiss in Taiwan and associated biophysical characteristics and histopathology. Bull Eur Assoc Fish Pathol 22: 319-327

Colorni A, Ravelo C, Romalde JL, Toranzo AE, Diamant A (2003) Lactococcus garvieae in wild Red Sea wrasse Coris aygula (Labridae). Dis Aquat Org 56(3):275-278

Cordwell SJ, Nouwens AS, Walsh BJ (2001) Comparative proteomics of bacterial pathogens. Proteomics 1(4):461-472

Cordwell SJ, Larsen MR, Cole RT, Walsh BJ (2002) Comparative proteomics of Staphylococcus aureus and the response of methicillin-resistant and methicillin-sensitive strains to Triton X-100. Microbiology 148:2765-2781

Crater DL, van de Rijn I (1995) Hyaluronic acid synthesis operon (has) expression in group A streptococci. J Biol Chem 270(31):18452-18458

Cunningham MW (2000) Pathogenesis of group A streptococcal infections. Clin Microbiol Rev 13(3):470-511

Eldar A, Perl S, Frelier PF, Bercovier H (1999) Red drum Sciaenops ocellatus mortalities associated with Streptococcus iniae infection. Dis Aquat Org 12:121-127

Fefer JJ, Ratzan KR, Sharp SE, Saiz E (1998) Lactococcus garvieae endocarditis: report of a case and review of the literature. Diagn Microbiol Infect Dis 32(2):127-130

Ferretti JJ, McShan WM, Ajdic D, Savic DJ and 19 others (2001) Complete genome sequence of an M1 strain of Streptococcus pyogenes. Proc Natl Acad Sci USA 98(8): 4658-4663

Görg A, Weiss W, Dunn MJ (2004) Current two-dimensional electrophoresis technology for proteomics. Proteomics (12):3665-3685

Hedstrom L (1999) IMP dehydrogenase: mechanism of action and inhibition. Curr Med Chem 6(7):545-560

Hughes MJ, Moore JC, Lane JD, Wilson R and 12 others (2002) Identification of major outer surface proteins of Streptococcus agalactiae. Infect Immun 70(3):1254-1259

Jungblut PR, Grabher G, Stoffler G (1999) Comprehensive detection of immunorelevant Borrelia garinii antigens by two-dimensional electrophoresis. Electrophoresis 20(18): 3611-3622

Kang SH, Shin GW, Shin YS, Palaksha KJ and 7 others (2004) Experimental evaluation of pathogenicity of Lactococcus garvieae in black rockfish (Sebastes schlegeli). J Vet Sci 5(4):387-390

Kawai K, Liu Y, Ohnishi K, Oshima S (2004) A conserved $37 \mathrm{kDa}$ outer membrane protein of Edwardsiella tarda is an effective vaccine candidate. Vaccine 22(25-26): 3411-3418

Kusuda R, Kawai K, Toyoshima T, Komatsu I (1976) A new pathogenic bacterium belonging to the genus Streptococcus, isolated from an epizootic of cultured yellowtail. Bull Jpn Soc Sci Fish 42:1345-1352

Lee EG, Kim JH, Shin YS, Shin GW and 5 others (2003) Establishment of a two-dimensional electrophoresis map for Neospora caninum tachyzoites by proteomics. Proteomics 3(12):2339-2350

Lehner I, Niehof M, Borlak J (2003) An optimized method for the isolation and identification of membrane proteins. Electrophoresis 24(11):1795-1808

Lei B, Mackie S, Lukomski S, Musser JM (2000) Identification and immunogenicity of group A Streptococcus culture supernatant proteins. Infect Immun 68(12):6807-6818

Len AC, Cordwell SJ, Harty DW, Jacques NA (2003) Cellular and extracellular proteome analysis of Streptococcus mutans grown in a chemostat. Proteomics 3(5):627-646

Lin D, Tabb DL, Yates JR (2003) Large-scale protein identification using mass spectrometry. Biochim Biophys Acta 1646(1-2):1-10

Marrakchi H, Dewolf WE Jr, Quinn C, West J and 8 others (2003) Characterization of Streptococcus pneumoniae enoyl-(acyl-carrier protein) reductase (FabK). Biochem J 370:1055-1062

Mortz E, Krogh TN, Vorum H, Görg A (2001) Improved silver 
staining protocols for high sensitivity protein identification using matrix-assisted laser desorption/ionization-time of flight analysis. Proteomics 1(11):1359-1363

Nakatsugawa T (1983) A streptococcal disease of cultured olive flounder. Fish Pathol 17:281-285

O'Farrell PH (1975) High resolution two-dimensional electrophoresis of proteins. J Biol Chem 250(10):4007-4021

Ooyama T, Hirokawa Y, Minami T, Yasuda H, Nakai T, Endo M, Ruangpan L, Yoshida T (2002) Cell-surface properties of Lactococcus garvieae strains and their immunogenicity in the yellowtail Seriola quinqueradiata. Dis Aquat Org 51:169-177

Pancholi V, Fischetti VA (1992) A major surface protein on group A streptococci is a glyceraldehyde-3-phosphatedehydrogenase with multiple binding activity. J Exp Med 176(2):415-426

Peir GB, Madin SH (1976) Streptococcus iniae sp. nov., a betahemolytic streptococcus isolated from an Amazon freshwater dolphin, Inia geoffrensis. Int J Syst Bacteriol 26:545-553

Perera RP, Johnson SK, Collins MD, Lewis DH (1994) Streptococcus iniae associated with mortality of Tilapia nilotica? T. aurea hybrids. J Aquat Anim Health 6:335-340

Polla BS, Mariethoz E, Hubert D, Barazzone C (1995) Heatshock proteins in host-pathogen interactions: implications for cystic fibrosis. Trends Microbiol 3(10):392-396

Rao PS, Yamada Y, Tan YP, Leung KY (2004) Use of proteomics to identify novel virulence determinants that are required for Edwardsiella tarda pathogenesis. Mol Microbiol 53(2):573-586

Rasch M, Buch C, Austin B, Slierendrecht WJ and 7 others (2004) An inhibitor of bacterial quorum sensing reduces mortalities caused by Vibriosis in rainbow trout (Oncorhynchus mykiss, Walbaum). Syst Appl Microbiol 27(3):350-359

Roberts RJ (2001) Fish pathology, 3rd edn. Saunders Publishing, Philadelphia, PA, p 324-325

Editorial responsibility: Carey Cunningham, Aberdeen, UK
Seng LT, Colorni A (2002) Infectious diseases of warmwater fish in marine and brackish water. In: Woo PTK, Bruno DW, Lim LHS (eds) Diseases and disorders of finfish in cage culture. CABI Publishing, Wallingford, p 193-230

Tettelin H, Nelson KE, Paulsen IT, Eisen JA and 35 others (2001) Complete genome sequence of a virulent isolate of Streptococcus pneumoniae. Science 293(5529):498-506

Tettelin H, Masignani V, Cieslewicz MJ, Eisen JA and 39 others (2002) Complete genome sequence and comparative genomic analysis of an emerging human pathogen, serotype V Streptococcus agalactiae. Proc Natl Acad Sci USA 99(19):12391-12396

Thongboonkerd V, Luengpailin J, Cao J, Pierce WM, Cai J, Klein JB, Doyle RJ (2002) Fluoride exposure attenuates expression of Streptococcus pyogenes virulence factors. J Biol Chem 277(19):16599-16605

Vytvytska O, Nagy E, Bluggel M, Meyer HE, Kurzbauer R, Huber LA, Klade CS (2002) Identification of vaccine candidate antigens of Staphylococcus aureus by serological proteome analysis. Proteomics 2(5):580-590

Weinstein MR, Litt M, Kertesz DA, Wyper P and 8 others (1997) Invasive infections due to a fish pathogen, Streptococcus iniae. S. iniae study group. N Engl J Med 337(9): 589-594

Winterhoff N, Goethe R, Gruening P, Rohde M, Kalisz H, Smith HE, Valentin-Weigand P (2002) Identification and characterization of two temperature-induced surfaceassociated proteins of Streptococcus suis with high homologies to members of the Arginine Deiminase system of Streptococcus pyogenes. J Bacteriol 184(24): 6768-6776

Yuasa K, Kitancharoen N, Kataoka Y, Abduljalil Al-Murbaty F (1999) Streptococcus iniae the causative agent of mass mortality in rabbitfish Siganus canaliculatus in Bahrain. J Aquat Anim Health 11:87-93

Submitted: March 31, 2005; Accepted: January 31, 2006

Proofs received from author(s): May 19, 2006 